\title{
Biological hazards in the pork chain continuum: Risk mitigation strategy
}

\author{
Nikola Betic ${ }^{l}$, Ivana Brankovic Lazic ${ }^{1}$, Ivan Nastasijevic ${ }^{*}$ \\ A b s $t$ r a c $t$ : The volume of pork meat production is continuously growing in the EU over previous years due to lower food \\ prices, higher number of reproduction sows and increased volume of pork exports to China. Consumer choices toward pork meat \\ depend on culture, place of residence and social opportunities, as well as their perception regarding safety and quality of pork meat/ \\ meat products. The main biological hazards associated with pork meat/meat products important from the public health perspective \\ are zoonotic food borne pathogens, bacteria and/or parasites, e.g. Salmonella spp., Yersinia enterocolitica, Listeria monocytogenes, \\ Trichinella spp., Toxoplasma gondii and Verotoxin-producing Escherichia coli (VTEC), by decreasing order, including associated \\ antimicrobial resistance (AMR). Pathways of infection and contamination of pork meat differ, taking into consideration the multiple \\ entry routes for zoonotic biological hazards along the pork meat chain, from farm to the final product. Therefore, the defined level of \\ safety of pork meat/meat products should be achieved by synergistic action of control measures effectively applied at different points \\ along the pork meat chain and supported by the integrated risk-based food (meat) safety management system in major modules of the \\ meat chain: pre-harvest (farm), harvest (slaughterhouse), post-harvest (meat processing, distribution, retail, consumers), as well as \\ identification and traceability. The integrated meat safety management system should be based on good hygienic practices (GHP) and \\ Hazard Analysis and Critical Control Points (HACCP) encompassing the science based hazard analysis and risk characterization, as \\ well as identifying the most effective control options and risk mitigation strategies in the pork meat chain continuum. \\ Keywords: pork meat, biological hazards, food safety, integrated approach.
}

\section{Introduction}

\subsection{Current status in the European Union}

The total number of pigs in Europe is 147.2 million. The volume of pig meat production increased by $1.3 \%$ in Europe from 2015 to 2016, and annual production of pig meat was 23.4 million tons. This growth trend is due to several reasons: lower food prices, higher number of reproduction sows and increased volume of pork exports to China (Eurostat, 2017). Consumption of pork per capita per annum in the European Union (EU) is $40.9 \mathrm{~kg}$ and growing (AHDB, 2015)

Consumer choices are certainly different depending on culture, place of residence and social opportunities. A basic rule for ethical food consumption is that the consumer knows what they are eating or purchasing. Therefore, product must carry a clear declaration where description of product ingredients, the information about manufacturer, the product processing method and the suitable storage conditions are stated (among other things) according to the EU regulation $(E U, 2011)$. Labels must be also clear and appropriate for the type of food, in accordance with the usual mode of food use, provide instructions for preparing the food and take account local customs. However, many declarations in the meat market show major and/or minor deviations from the prescribed rules. For such issues, food business operators (FBOs) are directly responsible, as are the competent authorities $(E U, 2002)$. In addition, the consumers also take over their level of responsibility regarding food safety and it is beneficial to provide the proper training to consumers, so that they are able to understand and apply all information given on label, in particular, regarding the intended use of the food product and food preparation in the kitchen (Henderikx, 2017).

\subsection{Epidemiology of pork meat-associated illnesses in the EU}

In 2016, campylobacteriosis was the most commonly reported zoonosis in the EU, accounting for almost $70 \%$ of reported cases. Other bacterial

${ }^{1}$ Institute of Meat Hygiene and Technology, Kacanskog 13, 11040 Belgrade, Republic of Serbia.

*Corresponding author: Ivan Nastasijevic, ivan.nastasijevic@inmes.rs 
diseases reported to a lesser extent were: salmonellosis, yersiniosis, verotoxin-producing Escherichia coli (VTEC) infections, and listeriosis. The most important biological hazards that affect human health associated with pork meat/meat products are Salmonella spp., Yersinia enterocolitica, Trichinella spp. and Toxoplasma gondii (Figure 1) (EFSA, 2017).

Salmonella: About 2,600 serovars of Salmonella spp. have been described so far. The five most important serovars that caused alimentary disorders in humans are $S$. Enteritidis, S. Typhimurium, monophasic S. Typhimurium, S. Infantis and S. Derby. The serovars that are the most common causes of human diseases associated with pork meat include: $S$. Typhimurium, and S. Derby. Within the EU, 25,049 units of fresh pig meat were examined microbiologically in 2016, of which $2.38 \%$ were positive for Salmonella spp.; 8,641 samples of meat prepared for use in the form of chopped meat were tested, with detected Salmonella prevalence of 1.93\%. In 2016, there were 94,530 confirmed cases of salmonellosis reported in the EU, with an incidence of 20.4 per 100,000 inhabitants (EFSA, 2017).

Yersinia. Twenty-six EU member states reported 6,861 confirmed cases of yersiniosis in 2016, with 1.82 reported cases per 100,000 inhabitants (EFSA, 2107). According to reports, Yersinia enterocolitica is the most reported Yersinia species in all countries, accounting for $99.1 \%$ of yersiniosis in the EU. A slightly higher yersiniosis incidence was reported in the period from May to August (EFSA, 2107).

Listeria. Based on the severity of zoonosis, listeriosis is one of the top-ranked as it can be associated with the fatal outcome. L. monocytogenes is a significant public health pathogen, because it is often found in foods. During 2016, 2,536 cases of listeriosis were reported and confirmed in the EU, i.e. 0.47 cases per 100000 inhabitants. The mortality rate among cases was $16.2 \%$, and it often occurred in people older than 64 years old, while the especially sensitive population are those older than 84 years. During 2016, in a survey carried out in the EU regarding different food categories, L. monocytogenes was detected in pig meat products (not including fermented sausage) in $3.1 \%$ of samples (EFSA, 2017).

Trichinella. In 2016, 101 cases of trichinellosis in humans, i.e., 0.02 cases per 100,000 inhabitants, were reported and confirmed in the EU, which was a decrease of $26.5 \%$ compared to the previous year. This is the lowest number of cases and the lowest rate of trichinellosis since implementation of EU-level reporting (EFSA, 2017).

Toxoplasma. One of the most recognized human and animal parasites is $T$. gondii, which has a global presence. Ingestion of viable cysts via

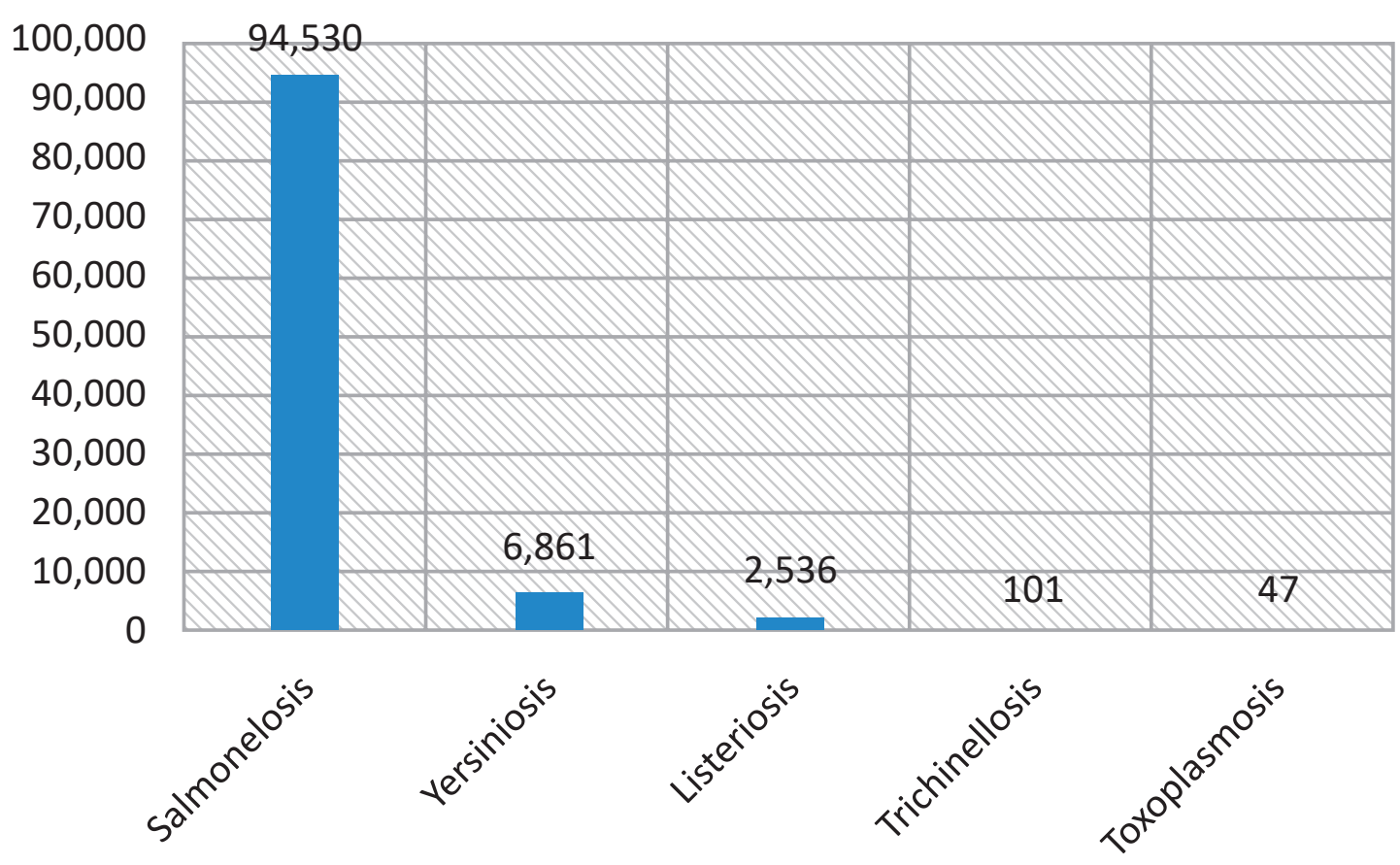

Figure 1. The incidence of food borne diseases caused by the main biological hazards associated with pork meat/meat products (EFSA, 2017) 
consumption of insufficiently thermally processed meat is considered one of the dominant ways human are infected with this parasite. During 2016, 47 cases of congenital toxoplasmosis were reported and confirmed in 19 EU Member States (MSs), with rate of 1.57 cases per 100,000 new-borns. It is not possible to estimate the prevalence of non-congenital toxoplasmosis, because only three MSs have an active control system for this disease (EFSA, 2017).

\subsection{Antimicrobial resistance (AMR)}

Excessive veterinary use of antimicrobial agents in animal species for food production, as well as the use in human population, contributes to the spread of AMR. Major zoonotic pathogens such as Salmonella spp. and Campylobacter, including those with AMR, can spread to humans by food and water consumption or by direct contact with animals. Several Salmonella spp. serotypes of public health significance were showed a high resistance rate to sulfisoxazole, tetracycline, ampicillin, ofloxacin, isolated from retail pork meat (Zhang et al., 2018). Commensal bacteria (E. coli, Enterococcus spp.) can also develop genetic resistance to antimicrobials, which can facilitate transmission of AMR to pathogenic bacteria that can cause diseases in humans and animals. The seriousness of this problem is the fact that more than 25,000 people die each year in the EU from diseases caused by antibiotic resistant bacteria. The use of antibiotics in food production systems has to be reduced, and compensated for by improvement of animal health through preventive measures and good hygiene and management practices (Nulty et al., 2016).

\subsection{Microbiological criteria for pork carcasses/ meat products}

To date, the best approach to ensure the food safety is a preventive, integrated approach, by managing all processes in food production, from primary production to the consumer. The main responsibility regarding food safety is related to Food Business Operators (FBOs), who define and implement appropriate measures for good hygienic and manufacturing practice, as well as other procedures based on Hazard Analysis and Critical Control Point (HACCP) principles, in order to achieve the food safety objectives (FSO) defined in food regulations. The numbers of aerobic bacteria (aerobic colony count/ACC) and Enterobacteriaceae (EC) and the presence/absence of Salmonella spp. are the process hygiene criteria defined for pig carcasses, after dressing-before chilling. ACC and E. coli counts are the process hygiene criteria for minced pork and pig meat preparations, at the end of the manufacturing process. The presence/absence of Salmonella spp. is also a food safety criterion, defining the counts/ limits for L. monocytogenes during the shelf-life of minced meat or meat preparations intended to be eaten cooked $(E U, 2005)$. There are also food safety criteria for L. monocytogenes in ready-to-eat (RTE) foods, which include cooked sausages, canned meats, and raw, dry fermented sausages. Therefore, pork meat/processed pork meat product placed on the market must, throughout its shelf-life, comply with food safety criteria that are clearly defined by the EU Regulation 2073/2005 (Table 1).

\section{Overview of biological hazards in the pork meat chain and risk ranking}

Hazards are defined as the biological, chemical or physical agents that can lead to illness or injury of consumers if adequate control measures are not in place. Biological hazards are organisms or agents of biological origin whose presence can make the product inappropriate or dangerous for consumption. Biological hazards include microorganisms (bacteria, viruses, fungi), parasites and prions. It is generally accepted that biological hazards are the major risk for meat consumers, especially due to their short term effects (Lawley et al., 2008).

\subsection{Farm}

The farm is the first link in the pig meat production chain. At the farm, biosecurity measures should be implemented and the principles of animal welfare should be fulfilled. Biosecurity measures should be part of a general strategy, developed in a close and continuous cooperation between the owner, employees and animal health expert. This cooperation should enable everyone in the team to be informed of relevant health questions at local, national and international levels.

Farm animals can be the primary source of human infection, directly through consumption of raw products or insufficiently thermally processed food derived from infected animals, or indirectly by spreading pathogens to plant products through fertilisers originating from infected animals. Therefore, it is very important to have knowledge of pathways of infection from the farm to final food products. 
Table 1. Food safety criteria and process hygiene criteria for minced meat, meat preparations and ready-to-eat $(E U, 2005$; Serbia, 2011)

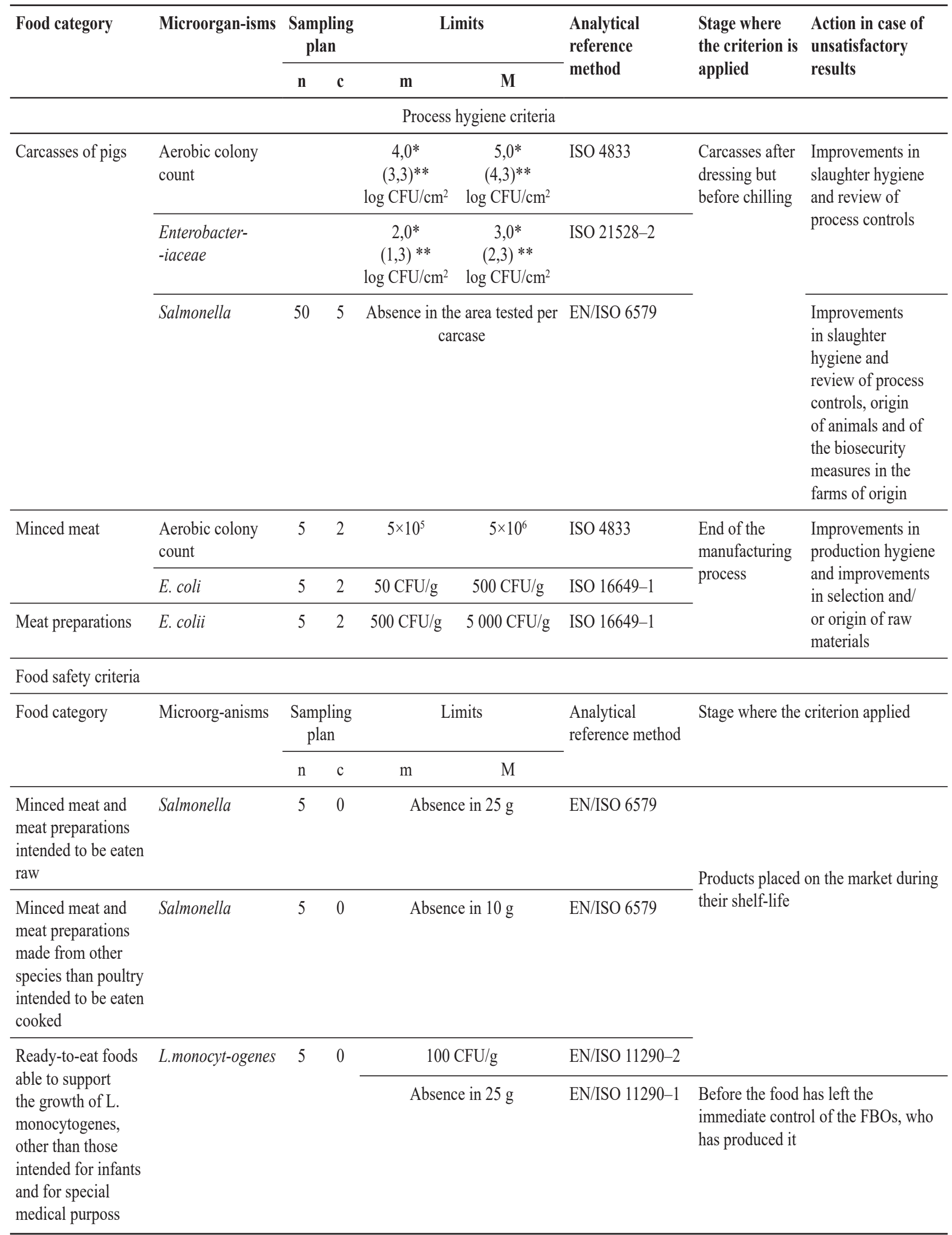

Legend: * Destructive method of swabbing; **Non-destructive method of swabbing; $\mathrm{n}=$ number of units comprising the sample; $\mathrm{c}=$ number of sample units giving values between $\mathrm{m}$ and $\mathrm{M}$ 
Pigs are sensitive to a wide spectrum of Salmonella spp., and young animals are more sensitive than older ones. Livestock can often be infected without any evident clinical symptoms of disease. Salmonellosis in pigs with clinical manifestations was often caused by $S$. Choleraesuis in the past, but with monitoring and control measures, the occurrence of this serotype on farms has been significantly reduced. S. Typhimurium is mostly transmitted among animals on the farm, while other serotypes mostly originate from food or the environment. (EFSA, 2017).

Among domestic animals, pigs are considered as the main reservoir of $Y$. enterocolitica, and they are asymptomatic carriers of this bacterium. Regarding control of food and animals, only a low number of EU member states reported data for 2016, which disables wider conclusions about its prevalence $(E F S A, 2017)$. The prevalence of $Y$. enterocolitica on some farms in the EU is ranging from $4 \%-93 \%$; some regional variations were also detected, which indicates the possibility of Yersinia control in pigs (Fredriksson-Ahomaa et al., 2000).

Livestock production, including pig farming in developed countries, is continuing to go through significant structural changes, including a significant reduction in the number of farms and a corresponding increase in capacity in closed systems, due to better efficiency and economic policy. However, at the same time, the number of smaller farms for growing pigs in the open is increasing. In farms with the open holding systems there is an increased risk of infection from T. gondii (Gamble et al., 1999; Garcia-Bocanegra et al., 2010). Indeed, the trend of breeding pigs in the open could have caused increases in pig seroprevalence for T. gondii. Also, in poorly managed systems, where pigs are bred in less controlled conditions, seroprevalence in pigs was as high as $68 \%$ (Gamble et al., 1999). It was suggested that low or negligible seroprevalence of $T$. gondii at farm level can be used as an indicator of good hygienic practice (van Knapen et al., 1995).

Consumers, especially residents of Europe and North America, often prefer organic meat from breeding systems that also recognise the animal welfare requirements. The consumer impression is that food produced by these principles can be automatically considered a safe food; however, according to the scientific research the situation is quite different. For example, keeping pigs in the open implies exposure of domestic pigs to increased risk of Trichinella spiralis, Trichinella britovi and Trichinella pseudintermedius infections originated from wildlife reservoirs (Burke et al., 2008).

\subsection{Slaughterhouse}

At slaughter, pathways of microbiological contamination are numerous and they can be categorised as internal or external. Meat originating from healthy, rested animals is normally sterile, but in stressed pigs, bacteraemia (bacteria in the bloodstream) can occur more easily (an internal contamination pathway). The external pathways of contaminating carcasses or pig meat can be direct, usually from skin of slaughtered animals, or indirect, e.g., skin-knife/equipment-meat.

Since the important source of Salmonella spp. in the meat production chain are the animals themselves, the prevalence of these bacteria on farm must be closely monitored (Korsak et al., 2003). Obviously, the Salmonella spp. prevalence in fresh meat is directly related to its prevalence in the animals, although the prevalence of this pathogen on/in pork meat in stages also depends on the further technological processing that meat undergoes as food.

Inadequate hygiene conditions and lack of sanitation procedures during transport of animals can contribute to the presence of bacteria on pig carcasses. Inadequately washed, dirty pigs originating from farms with poor hygiene contributes, can also increase the overall prevalence of microbes (e.g. ACC), including pathogens on/in pork meat. $E C$ are also very widespread in the environment, and they are also an integral part of the gastrointestinal microbiota of humans and animals. One of the most important places for contamination of pork skin with EC is the stunning box, which each pig touches. The technology of pig skin removal after slaughter also carries a high risk of contaminating carcasses/meat with $E C$ (Aslam et al., 2003). In addition, there is a high risk of meat contamination with gastrointestinal tract content during pig evisceration. Evisceration is the processing step that most contributes to bacterial contamination on carcass surfaces, because afterwards, there is no primary treatment that could reduce the number of bacteria. Inadequate procedures during technological operations at slaughter line (e.g. failure of workers to comply with work procedures, inadequate equipment, dirty work clothing, inadequate sanitation during work, not preventing cross-contamination) can lead to contamination of pig carcasses (Raseta et al., 2015). Cross-contamination at slaughter line is also a recognized issue from the perspective of meat safety, as confirmed by the increased prevalence of $S$. enterica from farm to slaughterhouse (De Busser et al., 2011; Karabasil et al., 2012). Although the contamination/infection of pigs with Salmonella spp. can happen at any point from the farm to the slaughterhouse, 
it should be emphasised that the slaughterhouse has an important role in this process. The surfaces in the lairage and in the stunning box are almost always contaminated with Salmonella and they can be sources of cross contamination, ultimately increasing Salmonella prevalences on carcasses at slaughter line (Nulty et al., 2016).

\subsection{Meat processing}

Meat products include products obtained by processing meat or further processing of such products, so that observation of a cross-sectional area indicates the product no longer has the characteristics of fresh meat. Depending on production methods, meat products can be classified into those produced without heat treatment and those produced with heat treatment. For example, fermented sausages are meat products produced without heat treatment, while pasteurised meat products are produced with heat treatment.

\subsubsection{Fermented sausages}

Fermented sausages are not heat treated, so after meat and fat tissue chopping and mixing, addition of ingredients (additives and spices), filling the mixture into casings, they are preserved by fermentation and drying, with or without smoking. The shelf-life of fermented sausages is determined by their low $\mathrm{pH}$ and water activities $\left(\mathrm{a}_{\mathrm{w}}\right)$, and therefore, they can be stored at higher (i.e., not chill) temperatures. Antimicrobial factors of importance for the safety and shelf-life of fermented sausages are: low $\mathrm{a}_{\mathrm{w}}$ of $0.80-0.90$, salt content of $2.4-2.8 \%, \mathrm{pH}$ of $5,3-6,0$ (Teodorović et al., 2015). As such, fermented sausage can be stored at a temperature of up to $5^{\circ} \mathrm{C}$.

For the production of fermented sausages, the meat of older animals is more suitable (older fattened pigs, sows excluded), because it contains more dry matter and more myoglobin pigment than young animals. $\mathrm{pH}$ has a very important role in the selection of pork cuts for fermented sausages, with recommended $\mathrm{pH}<6.0$. It is easier for meat with the lower $\mathrm{pH}$ values to release water, to dry easier, and which allows effective salt penetration. Much attention is given to selection of fat tissue, the most suitable of which is subcutaneous tissue of the neck and back (loin).

Starters are microbial cultures used to promote and conduct the fermentation of meat products. Bacteria, particularly lactic acid bacteria and coagulase-negative staphylococci, as well as yeasts and molds, may be used as starters (Laranjo et al., 2019). These are selected microorganisms that participate in the ripening of fermented sausages, and they are responsible for typical sensory properties of the final products. In fermented sausages, starter cultures ferment sugars to produce lactic acid and also have an important function in sausage maturation, including their protective role, e.g. micrococci produce the enzyme catalase, lactic acid bacteria produce antimicrobial substances. Catalase helps prevent oxidation because it decomposes hydrogen peroxide to water and molecular oxygen. Lactic acid bacteria produce organic acids, ethanol, hydrogen peroxide, carbon dioxide and bacteriocins, all of which can act antimicrobially (Laranjo et al., 2019).

Fermented dry sausages are mainly considered as a generally safe products from the microbiological aspect and their safety relies on these multiple antimicrobial properties, the so-called 'hurdle concept', e.g. $\mathrm{pH}, \mathrm{a}_{\mathrm{w}}$, redox potential (Leistner, 1994). During the past decade in the EU countries, epidemiological research showed the occurrence of disease outbreaks that were associated with the consumption of fermented sausages. The main bacterial hazards associated with this type of pork product are Salmonella spp., E. Coli and L. monocytogenes (Toldra, 2010). During production of dry fermented sausages, high initial contamination of raw meat or possibly contaminated sausage ingredients, as well as inadequate processing conditions and/or contamination after processing, can cause a risk of salmonellosis (Gieraltowsky et al., 2013). On the other hand, L. monocytogenes is of less concern if process hygiene is maintained at high levels during sausage production. Although contamination with this pathogen can occur in any phase of the sausage production process, it is more frequent in the latter stages of fermentation/ripening (Thevenot et al., 2005). Ensuring process hygiene during production is a key element for controlling this pathogen in food.

\subsubsection{Pasteurised meat products}

Pasteurised, heat-treated products include cooked sausages. Cooked sausages include numerous products that differ in diameter and fineness of their emulsified filling. Since they have a high $\mathrm{pH}(6.0-6.5)$ and $\mathrm{a}_{\mathrm{w}}(0.95-0.98)$, their shelf-life depends on appropriate heat treatment and storage temperature. Common to all cooked sausages is the meat emulsion that forms the basis of their stuffing, and which is filled into casings, their heat treatment at pasteurisation temperature, with or without smoke, or at boiling or sterilisation temperatures. Cooked sausages are most often processed by hanging in a controllable chamber containing steam at $75-85^{\circ} \mathrm{C}$ so that the core product temperature reaches at least $70^{\circ} \mathrm{C}$ for 20 minutes (Teodorović et al., 2015). These products 
are stored at $<4^{\circ} \mathrm{C}$ because this heat treatment cannot destroy all microorganisms, but only the vegetative forms of mesophilic and psychrophilic microorganisms.

\subsubsection{Canned meats}

Canned meats, like cooked sausages, usually have high $\mathrm{pH} 6,0-6,5$ and $\mathrm{a}_{\mathrm{w}} 0,96-0,98$ and their shelf-life also depends on appropriate heat treatment (commercial sterilization), hermeticity and storage temperatures. For canned meat production, meat with higher $\mathrm{pH}$ values is needed (Teodorović et al., 2015). While the use of warm meat would be ideal, a chilled meat is most commonly used in industrial production settings. Salting and chilling of meat are effective steps to reduce the number of aerobic bacteria, including Salmonella spp., but are less effective for E. coli (Sukumaran et al., 2018). Results in investigation Gabriel and Nakano (2009) about resistance among E. coli, L. monocytogenes and S. Enteritidis, it has been established that the L. monocytogenes is generally less susceptible to inactivation, and is even able to grow in the conditions found in many meat products, with the rate depending on different environmental factors (e.g., temperature, $a_{w}$ ). Temperature proved to be the most effective environmental factor for the growth and death of L. monocytogenes.

Table 2. Preliminary qualitative biohazard prioritisation in the pig meat chain (EFSA, 2012)

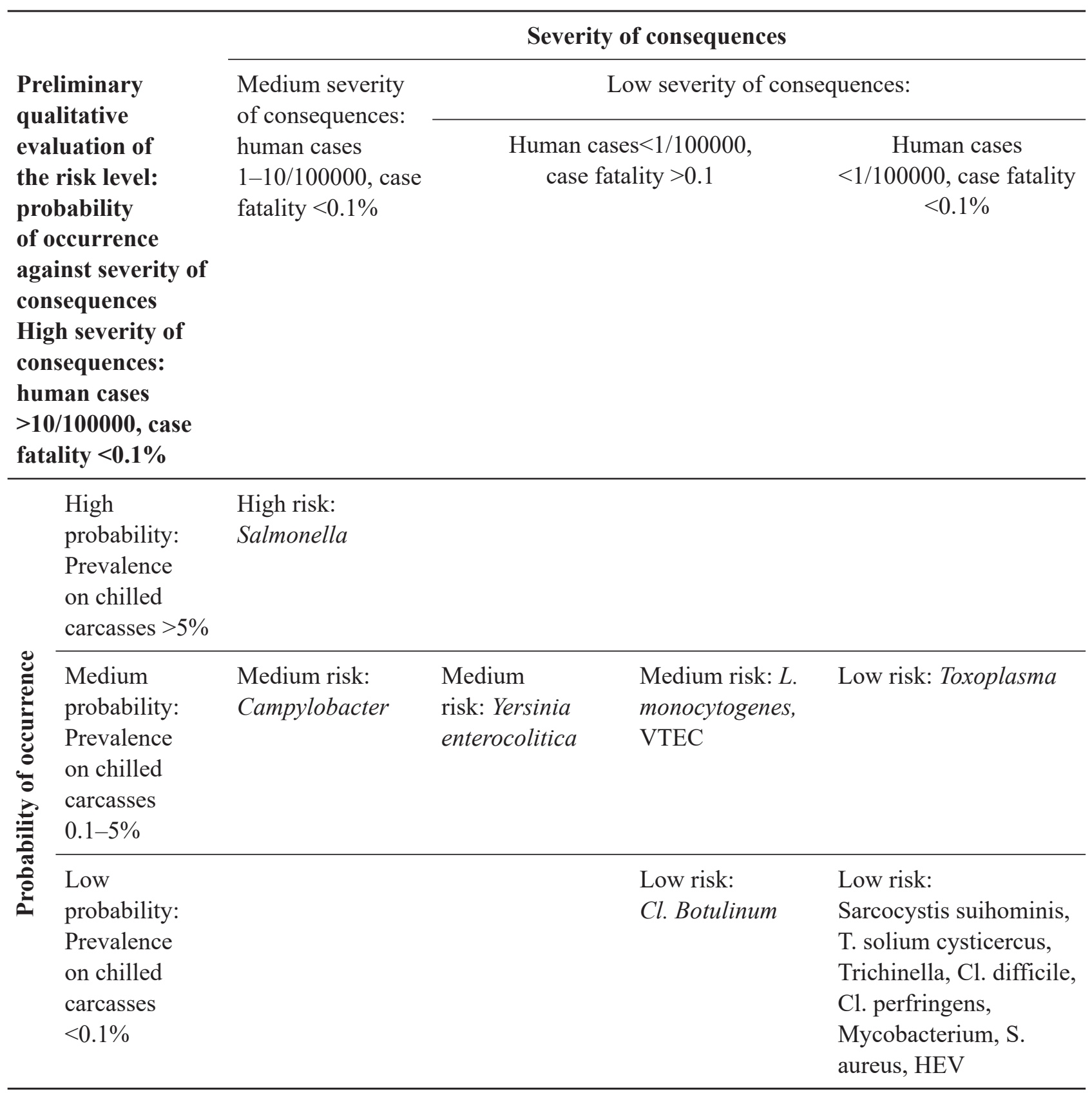




\subsection{Distribution/retail of meat and meat products}

Food safety is an imperative in international trade, so World Trade Organization (WTO) member states apply clearly defined sanitary and phytosanitary measures (SPS Agreement), based on appropriate risk assessment, to ensure that food safety and quality will not be compromised (WTO, 1995).

Phases of the meat distribution chain that are important in terms of transmission of pathogens include: 1) transport and storage between processing and wholesale or retail markets, 2) food handling and storage at retail, 3) transport from retail to home, as well as 4) handling and storage of food at home.

Special attention is given to the storage of foods. During storage, optimal conditions are provided to ensure a method of protection against air particle contamination, weather, animals (e.g., insects, birds) and sunlight, and maintaining hygienic conditions. Application of HACCP principles and good distribution practices should ensure conservation of food at the prescribed storage temperature (e.g. $<7^{\circ} \mathrm{C}$ for fresh meats, while recommended temperature for thermally processed meat products should be $\left.<4^{\circ} \mathrm{C}\right)(E U, 2004 ; F D A, 2018)$. The storage room should be designed to ensure efficient cleaning and maintenance and prevent microbial, chemical and physical cross-contamination.

Fresh meat is highly perishable and has a short shelf-life, which means the time available for product distribution is also short (Nastasijevic et $a l, 2017)$. If fresh meat and meat products are not kept in adequate, controlled temperatures, they can be good environments for the growth of pathogenic and other bacteria. The complexity of a global meat supply, in one country, between countries or between continents, requires cold chain solutions since product is acceptable to consumers only if it has the appropriate level of freshness and safety. Participants in the cold chain must cooperate, and they must have in mind the practices of previous and future participants. Therefore, the cold chain process must be documented. Although the importance of monitoring the correct cold chain temperatures is well known, this segment in the integrated meat supply chain is still a challenge. From recently, several tools impacting the cold chain have become recognized: biopreservation, ionising radiation, high hydrostatic pressure, active packaging, and wireless sensors connected to database software (Nastasijevic et al., 2017).

In the retail and consumer phases, the following risk factors can occur: inadequate storage, poor personal hygiene, contaminated equipment, and chemical residues. As for the consumer phase, other main risk factors include: inadequate cooking, and food from undocumented sources (FSIS, 2004).

\subsection{Ranking and prioritisation of biological hazards in the pork meat chain}

The prioritisation of biological hazards is made by taking into consideration public health data. For risk ranking biological hazards, i.e., prioritising them as of high, medium or low importance, the following data were used by European Food Safety Authority (EFSA, 2012): (i) Human incidence (EFSA/ECDC, 2011), (ii) Number of cases with fatal outcomes, (iii) Prevalence on pig carcasses (EFSA, 2009).

A qualitative risk assessment of biological hazards in the pig chain was conducted using chilled carcass' prevalence data, incidence and seriousness of the disease in humans and the attribution of hazards originating from pigs, in the EU. Based on this estimation, Salmonella spp. is considered as the main biological hazard originated from pigs, Y. enterocolitica, L. monocytogenes, VTEC and T. gondii are considered as medium risk hazards, while Trichinella spp. is of low risk (Table 2) (EFSA, 2012).

\section{Control measures for biological hazards in the pork meat chain}

Control measures are any actions or activities that are used to prevent or eliminate food safety hazards (Codex Alimentarius, 2005). The purpose of control measures is the production of food which is safe and suitable for human consumption. FBOs must be achieved by the implementation of the risk based meat safety assurance system (GHP/HACCP).

\subsection{Control measures on farm}

On-farm biosecurity measures include all measures and systems that prevent, eliminate or reduce biohazards. Effective on-farm biosecurity contributes to better animal health, higher productivity and profitability, food safety and environmental protection. Such measures also contribute to the better reputation of animal production in the country and affect international traffic of animals and products of animal origin (Figure 2) (Stanković and Hristov, 2010), On-farm risk factors are unique for each farm, and, thus, each biosecurity plan should be farm-specific. 


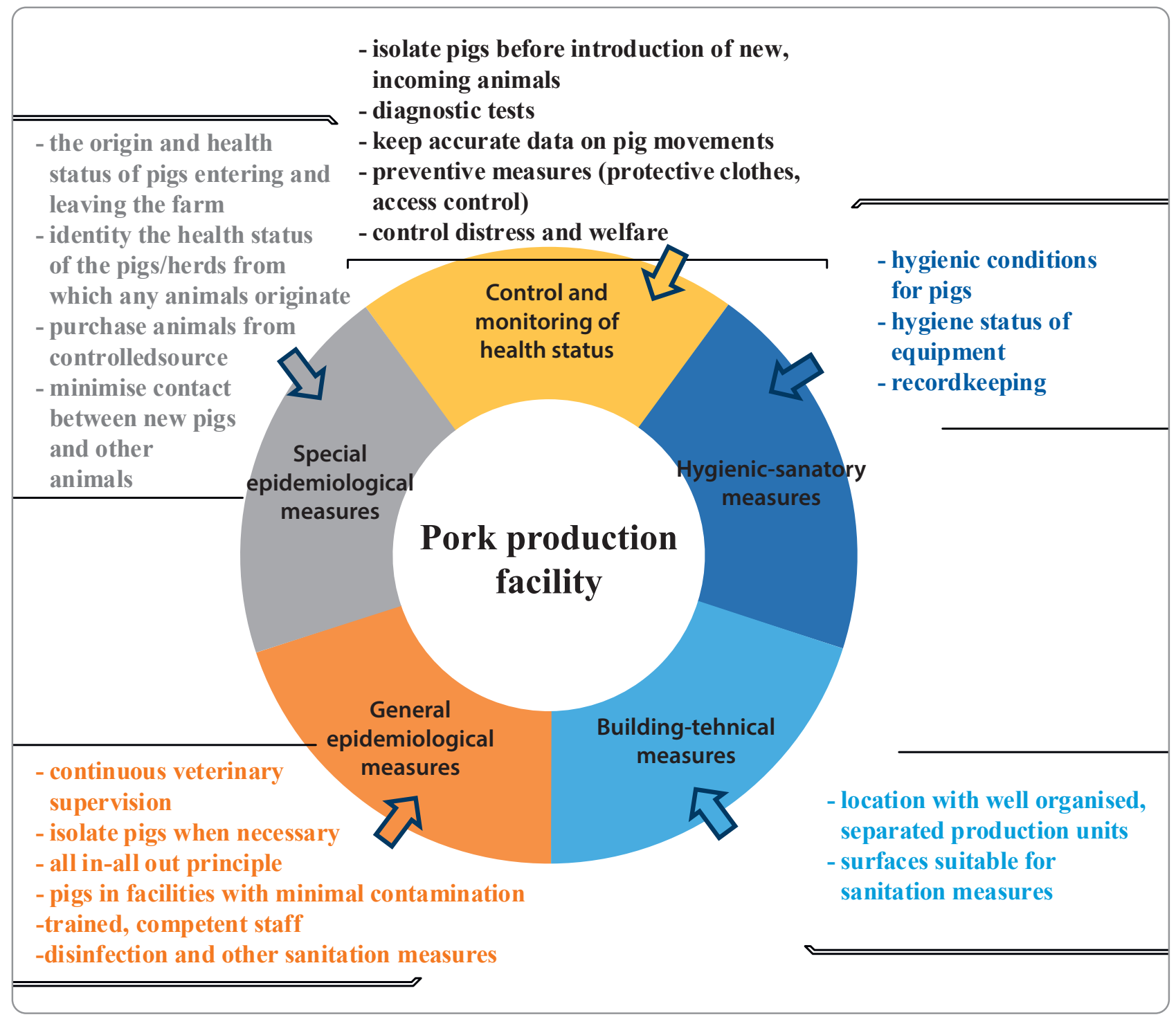

Figure 2. Overview of generic biosecurity measures on pig farm

\subsection{Control measures in slaughterhouse}

The competent authority or delegated inspection authority is obliged to check the Food Business Operator's (FBO) documentation and the applied self-control plans, including the set up microbiological criteria. The number or presence/absence of microorganisms on selected carcass surface sites of slaughtered pigs (Figure 3 ) is determined according to the standard methods (ISO, 2015). Time and frequency of sampling are regulated according to the: hygienic practice and technology for each slaughterhouse, design of risk-based process control or harmonised monitoring programmes, production volume, as well as epidemiological status of the area from which the animals originate.

The carcass sites from which samples are taken must be described in the self-control plan, which is defined by the FBO. Since the purpose is to examine those carcass sites where the probability of contamination is the greatest, standard sampling sites on pig carcasses are recommended, as shown in Figure 3 (ISO, 2015).

If Food Business Operator (FBO) decides to sample different carcass sites than those in Figure 3, they are required to validate their sampling method, i.e., to confirm that it achieves at least the same effect in monitoring carcass contamination that is achieved by using the recommended system. Importantly, the defined carcass sites are sampled over time in order to monitor trends of the results obtained. EU regulation $(E U, 2005)$ requires that FBOs analyse test result trends to enable appropriate measures to be taken without delay in the case of unsatisfactory trends. This is in order to limit or prevent the occurrence of 


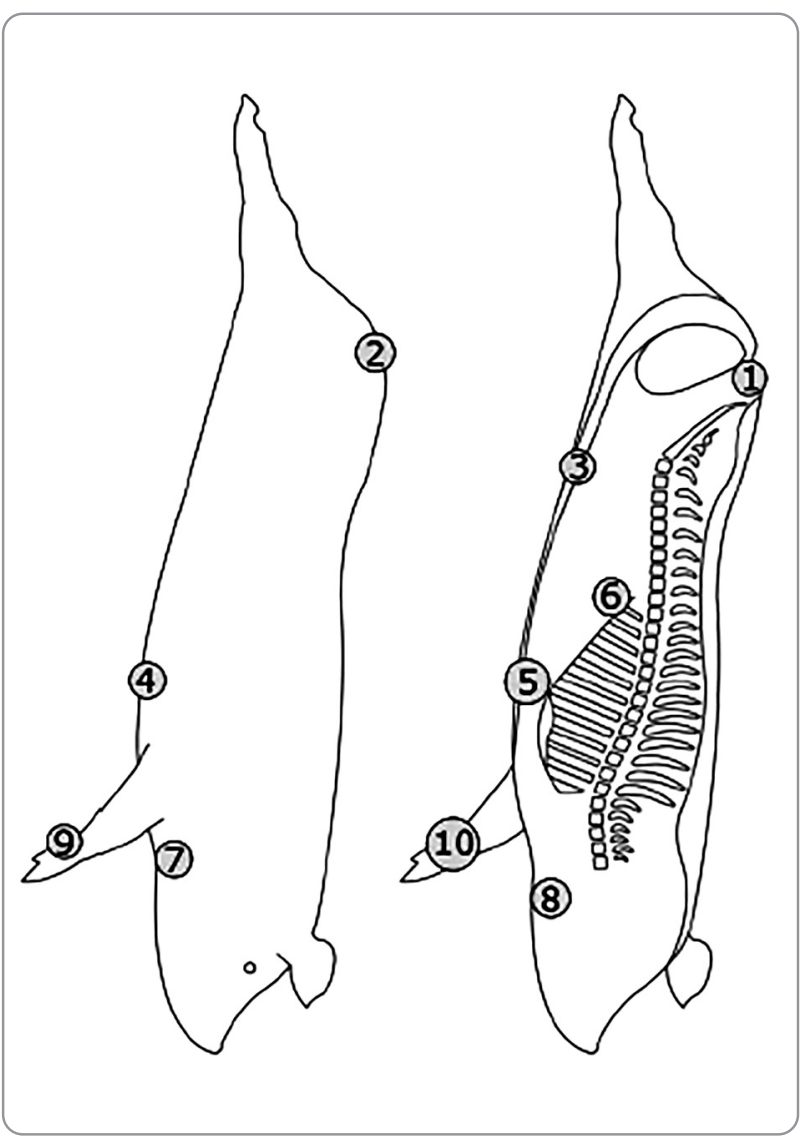

Figure 3. Suitable sites for taking samples from pig carcasses (ISO, 2015). Sites are: 1) Pelvic channel internal, 2) Pelvic channel external, 3) Abdominal,

4) Xiphoid external, 5) U Xiphoid internal,

6) Pillar of diaphragm, 7) Submaxillary external,

8) Submaxillary internal, 9) Forefoot external aspect, 10) Forefoot internal aspect microbiological hazards. Slaughterhouses must conduct self-control checks every week, and the day of sampling must be changed every week, to ensure coverage of every day of the week. In case that results were satisfactory within the six consequtive weeks in a row (ACC, EC), FBOs can reduce sampling at once per two weeks/fortnightly (Serbia, 2011).

Samples are taken from the suitable sites on carcass surfaces by destructive or non-destructive sampling methods, after carcasses are washed, but before chilling. Destructive methods disturb the integrity of carcasses, by cutting and removing tissue samples from the depth of meat. Non-destructive methods involve swabbing carcass surfaces without disturbing the integrity of carcasses. Destructive methods give more precise results and show a higher level of carcass contamination than non-destructive methods. However, the destructive methods have negative consequences on carcass values, so the use of these techniques is limited. Certainly, non-destructive methods are more practical and economical in field conditions and are the most common sampling methods to monitor hygiene of pig carcass production processes.

The microbiological criteria for the hygiene of the production process for pig carcasses are: the aerobic colony count (EN ISO 4833), Enterobacteriaceae count (EN ISO 25528-2) and the presence/absence of Salmonella spp (EN ISO 6579) (Table 1). To obtain the aerobic colony count and number of Enterobacteriaceae, laboratory test results are shown as the number of colony forming units per $\mathrm{cm}\left(\mathrm{CFU} / \mathrm{cm}^{2}\right)$ for each collective sample taken from one carcass. The daily average logarithmic value is obtained by calculating the logarithm $\left(\log _{10}\right)$ of each individual laboratory test result/per

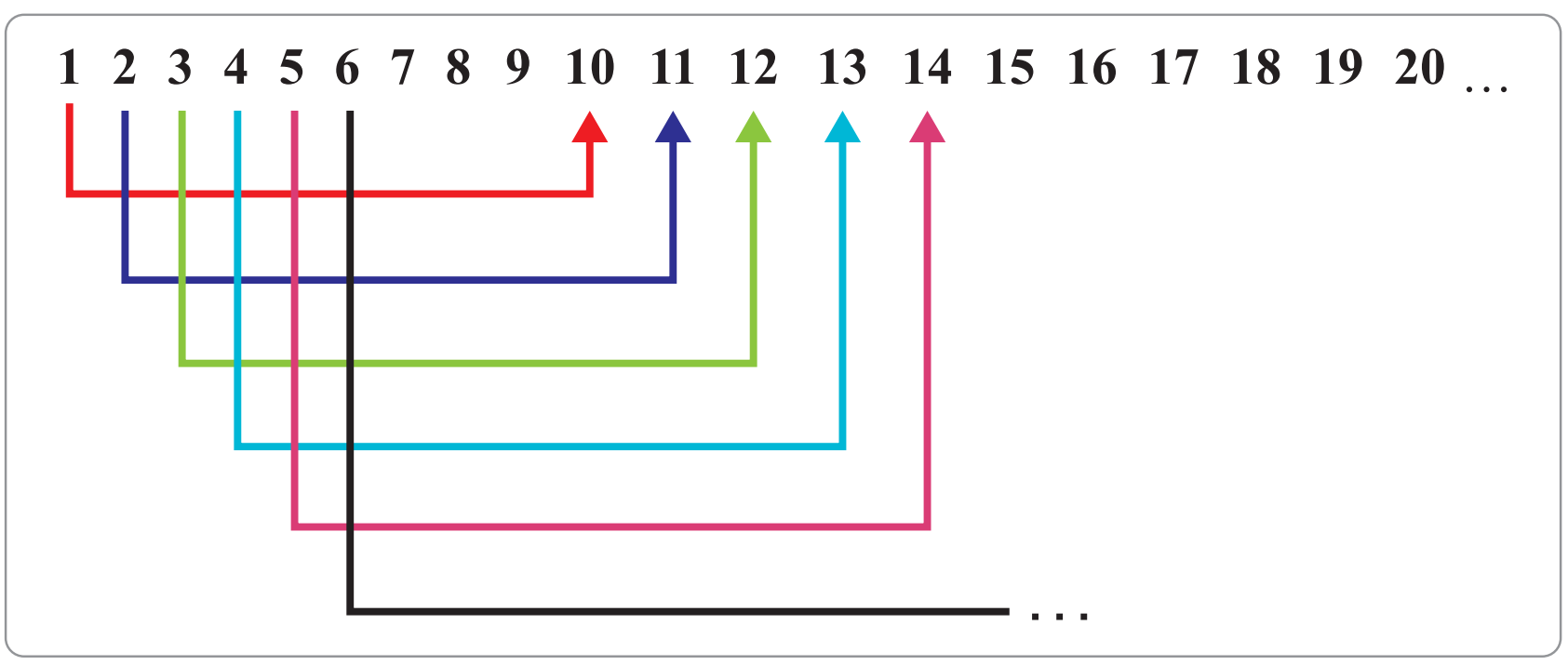

Figure 4. Sampling on the principle of a moving window (Serbia, 2011) 
carcass site, and then calculating the average of these logarithmic values. The limit values for pig carcasses are shown in Table 1. In the case of unacceptable test results, improvement of slaughter hygiene and a review of process control must be undertaken.

The criterion for Salmonella spp. on pig carcasses is defined in the food safety criteria, as well as in the criteria for process hygiene $(E U, 2005$; Table 1). To determine the presence/absence of Salmonella spp. on slaughtered pig carcasses, a non-destructive method of sampling with abrasive sponges is normally used. The sampling area must cover at least $400 \mathrm{~cm}^{2}$, and five samples are taken from the pre-determined sampling sites. The serial trend results of Salmonella spp. presence/absence determination on pig carcasses are calculated from 50 samples collected over 10 consecutive samplings. This means the number of samples that contained Salmonella spp. is calculated after 10 consecutive weeks from the five samples taken each week (Table 1). The second series include samples taken from $2^{\text {nd }}$ to the $11^{\text {th }}$ week, the third from the $3^{\text {rd }}$ to the $12^{\text {th }}$ week, etc. Estimation of the trend of the successive sampling is based on the rolling window principle (Figure 4).

Corrective measures in the case of unacceptable trend results encompass the improvement of slaughter hygiene and the review of process control, as well as the origin of the pigs, including the improvement of biosecurity measures on farm of origin.

\subsection{Control measures for pasteurised and fermented pork meat products}

Food safety criteria are applied to meat and meat products (food) placed on the market and are applicable throughout the food's shelf-life $(E U, 2005)$. When defining the microbiological criteria that are applied to a particular type of meat product, the way in which the product is consumed is taken into consideration, but it is also important to consider the specific (vulnerable) groups of consumers for whom it is intended, and the fate of the defined hazard in the food, e.g. YOPI (young, old, pregnant, immunocompromised).

Ready-to-eat (RTE) meat products do not require further thermal or other processing that would eliminate or reduce to an acceptable level the number of microorganisms defined as potential hazards in the product. However, RTE meat products that could support the growth of L. monocytogenes could pose a risk to human health. In such cases, the FBO must conduct a product shelf-life study, to determine the compliance with the microbiological criteria for $L$. monocytogenes during the product shelf-life $(E U, 2005)$.
In the EU, to select the appropriate food safety criterion for L. monocytogenes in ready-to-eat meats, the food category must first be determined. RTE foods are classified into two categories based on the growth of $L$. monocytogenes in the food: a) RTE food that supports growth of L. monocytogenes; b) RTE food that does not support growth of $L$. monocytogenes $(E U, 2005)$. To define the category b), it is considered that food should have any of the three following properties which means that such product does not support the growth of L. monocytogenes: 1) $\mathrm{pH}<4.4$ or $\mathrm{a}_{\mathrm{w}} \leq$ $0.92 ; 2) \mathrm{pH}<5.0$ or $\mathrm{a}_{\mathrm{w}} \leq 0.94 ; 3$ ) shelf-life $<5$ days.

In case of food that supports growth of $L$. monocytogenes (category a), FBO should validate the production process for respective products applying 'double' criterion: (i) confirmation of L. monocytogenes absence in the product, in five $25 \mathrm{~g}$ samples, before the food has left the immediate control of the FBOs, and (ii) confirmation that numbers of L. monocytogenes in the product will not exceed 100 $\mathrm{CFU} / \mathrm{g}$ throughout the product shelf-life, where the L. monocytogenes criterion of fewer than $100 \mathrm{CFU} / \mathrm{g}$ in each of five samples of product is applied. In these foods, the FBO can determine temporary limit values to use during processing, which must be low enough to guarantee the number of $L$. monocytogenes will not exceed $100 \mathrm{CFU} / \mathrm{g}$ throughout the product shelf-life.

In the EU, criteria for Salmonella spp. in pork meat products and pig carcasses are applied (i.e. food safety and process hygiene criteria, respectively). For pork meat products, the FBO must conduct a sampling plan in accordance with the food safety criteria for: a) minced meat and meat preparations made from other species than poultry intended to be eaten cooked, and; b) meat products intended to be eaten raw, excluding products where the manufacturing process or the composition of the product will eliminate the Salmonella risk. Salmonella spp. must not be found in five samples, each being $25 \mathrm{~g}$ of product and the criteria are applied to the products throughout their shelf-life (Table 1). Process hygiene criterion regarding Salmonella for pig carcasses is described in Table 1 and Figure 4. The results of the test show the microbiological validity of the examined series and can be used to demonstrate the effectiveness of the HACCP system or good hygienic practice of the process $(E U, 2005)$.

In cases where the results of the test are unsatisfactory, the FBO is obliged to take corrective measures: pull-back or recall of food, identify and remove the causes, check that the process is under control again, reassess defined and applicable risk prevention and other available risk management measures. 


\subsection{Control measures in the distribution/retail chain}

To maintain food safety, it is important that the cold chain is interrupted after pig slaughter and processing, and throughout all stages of the processing/ distribution/retail chain (Nastasijevic et al., 2017). Meat and meat products must be distributed to retailers by vehicles dedicated for that purpose, and which must comply with the above conditions. After delivery, meat and meat products are stored at an adequate chill temperature and in an appropriate manner that prevents cross-contamination with foodborne pathogens. At the consumer level, the general hygiene principles recommended by the World Health Organization (WHO) which should be applied are five keys for safer foods: maintain personal hygiene (hand hygiene), separate raw food from thermally processed food, cook food thoroughly $\left(>70^{\circ} \mathrm{C}\right)$, store food at safe temperatures (below $5^{\circ} \mathrm{C}$ or above $60^{\circ} \mathrm{C}$ ), use potable water for food preparation and use safe materials for food preparation (WHO, 2006). Continuing education for FBOs and consumers is necessary, as well. In Serbia, following the official introduction of the new legislation that required HACCP implementation (Serbia, 2005; 2009), the process hygiene in food establishments was significantly improved compared to the hygiene levels in the period prior to HACCP implementation (Tomasevic et al, 2016).

\section{Risk mitigation strategy for biological hazards in the pork meat chain}

Salmonella spp., Y. enterocolitica, T. gondii, and Trichinella spp. are recognised as the most important biological hazards originated from pork meat that can affect human health $(E F S A, 2012)$. To obtain adequate level of safety of pork meat products and reduce foodborne outbreaks originated from pork meat/products, the pork meat production chain must comply with some well-described principles. Those principles are related to the integrated control along the whole meat production chain in the context of Longitudinally Integrated Safety Assurance (LISA concept), which include synergistic implementation of control measures in the farmto-distribution continuum (Nastasijevic et al, 2016).

Farm. On-farm biosecurity measures include all measures and systems on-farm that prevent, eliminate or reduce biohazards. Biosecurity measures must be implemented on pig farms, as their effective use contributes to better animal health, higher productivity and profitability, food safety and environmental protection.
Slaughterhouse. Adequate conditions must be allowed during loading, transporting and unloading pigs from farm to slaughterhouse. Pigs should be washed, clean and originate from farms where suitable biosecurity measures are applied, as there may be cross-contamination in the slaughterhouse, which is a significant problem from the aspect of food safety. The lairage surfaces and the stunning box are regularly contaminated with Salmonella spp. and can be sources of cross-contamination of animals, as well as the carcasses on the pig slaughter line. Enterobacteriaceae, as part of the gastrointestinal tract, are very widespread in the environment, and importantly, often contaminate the stunning box. Therefore, the principles of good hygiene (GHP) and good manufacturing practice (GMP) must be applied. The production process hygiene is determined using microbiological criteria for pig carcasses (Table 1): the aerobic colony count, Enterobacteriaceae count and presence/absence of Salmonella spp.

Meat processing. Products obtained by meat processing, and which no longer have the characteristics of fresh meat, must be produced using good hygienic/manufacturing practices. Initial contamination of raw materials with pathogenic bacteria must be limited, while processing conditions must be adequate and/or contamination after processing must be prevented, in order not to impair the product safety. Criteria are clearly defined for pork meat and meat products by determining the growth or presence/absence of pathogenic bacteria in products during their shelf-life (Table 1).

Distribution. To maintain meat and meat product safety from slaughterhouse to the consumer, the continuity of the cold chain should be maintained to encompass the consumer phase (Codex Alimentarius, 2005). In addition to adequate temperature, good distribution practices must be implemented and cross-contamination of pig meat with biohazards be prevented.

\section{Conclusion}

As world trade increases and the population grows up, food safety is more important than ever, and states must comply with clearly defined conditions for food production. Pork meat production increased by $1.3 \%$ in Europe in 2016, and annual production was 23.4 million tons. Significant numbers of foodborne illnesses have been associated with this large production volume of pork meat. The biohazards, Salmonella spp., Y. enterocolitica, T. gondii, and Trichinella spp. are recognised as the most important hazards that can affect human health and can originate 
from pigs/pork meat. Integrated monitoring and control of biohazards, along the pork meat chain, including associated AMR, commensal and zoonotic bacteria in humans, animals and food are necessary as an important source of information for improving food safety and consumer protection. Infection and contamination pathways of pork meat are different, but biohazards can reach the food in each step from farm until consumption. Pigs can be the primary source of infection of humans, directly via raw pork or insufficiently thermally processed meat products from infected pigs or contaminated meat, or indirectly via spread of biohazards on plants via fertilisers that originate from infected pigs. On-farm biosecurity measures contribute to improved animal health, increased production and profitability, food safety and environmental protection. Microbiological contamination of pork meat can have a source and/or occur at multiple stages along the meat chain, which are generally divided into internal (distress on-farm/in transportation/ lairage which may lead to increased faecal shedding of major zoonotic food borne pathogens) and external factors (dirtiness/cleanliness of incoming animals, meat handlers, tools, equipment, air). The following microbiological indicators are used to assess slaughter process hygiene for pig carcasses: aerobic colony counts (ACC) - indicate the level of general hygiene, Enterobacteriaceae counts (EC) - indicate the faecal contamination and presence/absence of Salmonella spp. - indicate the occurrence of pathogen on farm. In the EU, FBOs are required to analyse process hygiene trends; when a trend is unsatisfactory, appropriate corrective measures must be applied without delay to prevent the unacceptable occurrence of microbiological hazards. EU legislation requires slaughterhouses to perform self-controls every week, with sampling days changing constantly to ensure coverage of all days in the week. Food safety management must be based on a good production/hygienic practices and effective risk-based food safety management system (HACCP), which requires the FBO to recognise, control and/or eliminate relevant hazards that could compromise product safety in proactive manner. The main purpose of laboratory examination of final products is to provide the validation whether food safety management systems operates effectively. The distribution chain requires that meat products should be protected from the contamination, so dedicated vehicles must be properly cleaned, washed and disinfected. For temperature-sensitive meat/meat products, a vigorous cold chain must be maintained from the producer to the consumer. Interruption of one or more components in the distribution chain may provoke consequent damage of the meat/meat products and, therefore, affect the consumers' health, as well as excessive economic damage due to food recalls.

\title{
Integrisani pristup upravljanju biološkim opasnostima u lancu proizvodnje svinjskog mesa i proizvoda od svinjskog mesa u kontinuumu farma-klanica-prerada mesa-distribucija
}

\author{
Nikola Betić, Ivana Branković Lazić, Ivan Nastasijević
}

A p s $t$ r a k $t$ : Obim proizvodnje svinjskog mesa ima trend rasta na teritoriji EU, uz trend rasta proizvodnje pristune su $i$ biološke opasnosti koje utiču na bezbednost hrane. Samonella spp, Yersinia enterocolitica, VTEC, Toxoplasma gondii, Trichinella spp.i L. monocytogenes su prepoznati kao najvažniji biološki agensi koji utiču na zdravlje ljudi, poreklom od svinjskog mesa i proizvoda odsvinjskog mesa. Neophodan je integrisani monitoring i kontrola bioloških opasnosti, kao i kontrola antimikrobne rezistencije (AMR) komensalnih $i$ zoonotskih bakterija kod ljudi, životinja i hrane kao važan izvor informacija za poboljšanje bezbednosti hrane $i$ zaštite potrošača. Putevi infekcije i kontaminacije svinjskog mesa su različiti i mogu se desiti u svim procesima proizvodnje od famre do finalnog proizvoda. Bezbednost hrane bi trebalo bazirati na dobroj proizvodjačkoj/higijenskoj praksi i HACCP sistemu, koji od subjekta u poslovanju hranom zahteva da prepozna opasnost koja može da utiče na bezbednost hrane, da opasnost kontroliše i eliminiše. Integrisani sistem u proizvodnji svinjskog mesa i proizvoda od svinjskog mesa mora da se bazira na identifikaciji $i$ sledljivosti $u$ kontinuити farma-klanica-prerada-distribucija.

Ključne reči: biološke opasnosti, lanac bezbednosti hrane, proizvodnja svinjskog mesa, integrisani pristup.

Disclosure statement: No pontential conflict of interest reported by authors. 


\section{References}

AHDB (Agriculture and Horticulture Development Board) (2015). United Kingdom. https://pork.ahdb.org.uk/prices-stats/news/2016/march/eu-pig-meat-consumption-rises-in-2015/ (accessed on 01 December 2018).

Aslam, M. F., Nattress, G., Greer, C., Yost, C. \& McMullen, L. G. (2003). Origin of contamination and genetic diversity of Escherichia coli in beef cattle. Applied Environmental Microbiology, 69, 2794-2799.

Burke, R., Masuoka, P. \& Murrell, K. D. (2008). Swine Trichinella infection and geographic information system tools. Emerging Infections Diseases, 14. 1109-1111.

Codex Alimentarius (2005). Code of hygienic practice for meat CAC/RCP 58-2005:1-51.

De Busser, V. E., Maes, D., Houf, K., Dewulf, J., Imberechts, H., Bertrand, S. \& De Zutter, L. (2011). Detection and characterization of Salmonella in lairage, on pig carcasses and intestines in five slaughterhouses. International Journal of Food Microbiology 145, 279-86.

EFSA (2009). Analysis of the baseline survey on the prevalence of Salmonella in holdings with breeding pigs in the EU, 2008 — Part A: Salmonella prevalence estimates. EFSA Journal, 7(12):1377.

EFSA/ECDC (2011). The European Union Summary Report on Trends and sources of Zoonoses, Zoonotic Agents and Food-borne Outbreaks in 2009. EFSA Journal, 9(3):2090.

EFSA (2012). Scientific Opinion on the development of a risk ranking framework on biological hazards, Panel on Biological Hazards, Parma, Italy. EFSA Journal, 10(6): 2724.

EFSA (2017). The European Union summary report on trends and sources of zoonoses, zoonotic agents and food-borne outbreaks in 2016. EFSA Journal, 15(12):5077.

EU (2002). Regulation No. 178/2002 of the European Parliament and of the Council of 28 January 2002 laying down the general principles and requirements of food law, establishing the European Food Safety Authority and laying down procedures in matters of food safety. L 31, 1-24.

EU (2004). Regulation No. 853/2004 European Parliament and of the Council of 29 April 2004 laying down specific hygiene rules for on the hygiene of foodstuffs. L 139, 55.

EU (2005). Commission Regulation 2073/2005 on microbiological criteria for foodstuffs. L 338, 1.

EU (2011). Regulation (EU) No. 1169/2011 of the European Parliament and of the Council of 25 October 2011 on the provision of food information to consumers. L 304, 18-63.

Eurostat (2017). Agricultular production — animals. https://ec. europa.eu/eurostat/statistics-explained/pdfscache/27963. pdf (accessed on 01 December 2018).

Fredriksson-Ahomaa, M., J. Björkroth, S. Hielm \& Korkeala H. (2000). Prevalence and characterization of pathogenic Yersinia enterocolitica in pig tonsils from different slaughterhouses. Food Microbiology 17, 93-101.

FSIS (Food Safety and Inspection Service). (2004). USA https://www.fsis.usda.gov/wps/wcm/connect/f97af 92f-d089-459c-b6976d696993c4d3/Sweden2003. pdf?MOD=AJPERES (accessed on 01 December 2018).

FDA (2018). Refrigerator \& freezer storage chart. https://www.fda.gov/food/people-risk-foodborne-illness/ refrigerator-freezer-chart-food-safety-moms-be (accessed on 08 May 2018).

Gabriel, A. A., Nakano, H. (2009). Responses of E. coli O157:H7, L. monocytogenes $1 / 2 \mathrm{c}$ and Salmonella enteritidis to $\mathrm{pH}, \mathrm{a}_{\mathrm{w}}$ and temperature stress combinations. Food Control 21, 644-650.

Gamble, H. R., Brady, R. C. \& Dubey, J. P. (1999). Prevalence of Toxoplasma gondii infection in domestic pigs in the New England states, Veterinary Parasitology 82, 129-136.

García-Bocanegra, I., Simon-Grifé, M., Dubey, J. P., Casal, J., Martín, G. E., Cabezón, O., Perea, A. \& Almería, S. (2010). Seroprevalence and risk factors associated with Toxoplasma gondii in domestic pigs from Spain. Parasitology International 59, 421-6.

Gieraltowsky, L., Julian, E., Pringle, J., Macdonald, K., Quilliam, D. \& Marsden-Hang, N. (2013). Nationwide outbreak of Salmonella Montevideo associated with contaminated imported black and red pepper: warehouse membership cards provide critical clues to identify the source. Epidemiology and Infection 141, 1244-1252.

Henderikx, F. (2017). Labelling of food: A challenge for many. Veterinarski Glasnik, 71(1), 16-23.

ISO (2015). ISO 17604. Microbiology of the food chain: Carcass sampling for microbiological analysis.

Karabasil, N., Pavlicevic N., Galic N., Dimitrijevic M., Loncina, J., Ivanovic, J. \& Baltic, M. (2012). Salmonella on pig carcasses during slaughter and processing. Veterinarski Glasnik 66, 377-386.

Korsak, N., Jacob, B., Groven, B., Etienne, G., China, B., Ghafir, Y. \& Daube, G. (2003). Salmonella Contamination of Pigs and Pork in an Integrated Pig Production Systems. Journal of Food Protection, 66, 1126-33.

Laranjo, M., Potes, M. E., Elias, M., (2019). Role of Starter Cultures on the Safety of Fermented Meat Products. Frontiers in Microbiology, 10, 853.

Lawley, R., Curtis, L., \& Davis, J. (2008). The food safety hazard guidebook. Cambridge, UK, RSC Publishing.

Leistner, L. (1994). Further developments in the utilization of hurdle technology for food preservation. Journal of Food Engineering, 22,421-432.

Lina Zhang, Ying Fu, Zhiying Xiong, Yeben Ma, Yihuan Wei, Xiaoyun Qu, Hongxia Zhang, Jianmin Zhang, Ming Liao. (2018). Highly Prevalent Multidrug-Resistant Salmonella From Chicken and Pork Meat at Retail Markets in Guangdong, China. Frontiers Microbiology, 10. doi: 10.3389/fmicb.2018.02104.

Nastasijevic, I., Tomasevic, I., Smigic, N., Milicevic, D., Petrovic, Z. and Djekic, I. (2016). Hygiene Assessment of Serbian Meat Establishments Using Different Scoring Systems. Food Control 62, 193-200.

Nastasijevic I., Lakicevic B. \& Petrovic, Z. (2017). Cold chain management in meat storage, distribution and retail: A review. IOP. Vol.85. doi: 10.1088/1755-1315/85/1/012022.

Nulty K. M., Soon J. M., Wallace C. A. \& Nastasijevic I. (2016). Antimicrobial resistance monitoring and surveillance in the meat chain: A report from five countries in the European Union and European Economic Area. Trends in Food Science and Technology, 58, 1-13. 
Raseta, M., Teodorovic V., Jovanovic, J., Lakicevic, B., Brankovic-Lazic, I. \& Vidanović, D. (2015). Process hygiene of pig carcasses during one year at a slaughterhouse in the North Banat District of Serbia. Tehnologija Mesa, 56 (1), 26-33.

Serbia (2005). Veterinary law. Official Gazette of the Republic of Serbia, No. 91/05.

Serbia (2009). Food safety law. Official Gazette of the Republic of Serbia, No. 91/05.

Serbia (2011). Guide to the application of microbiological criteria for food, first edition. http://www.vet.minpolj.gov. rs/veterinarsko javno zdravstvo/instrukcije i vodici/Vodic $\% 20 \mathrm{z} \quad$ a $\% 20$ mikrobioloske $\% 20$ kriterijume $\% 20$ za\%20hranu.pdf (accessed on 01 December 2018).

Stanković, B. \& Hristov, S. (2010). Biosecurity on pig farms and farm security. http://www.vet.minpolj.gov.rs/zdravstvena\%20zastita/kompenzacioni\%20fond/dokumenta/Biosigurnost $\% 20$ na\%20farmama\%20svinja1.pdf (accessed on 01 December 2018).

Sukumaran, T. A., Holtcamp, J. A., April K. Englishbey, K. A., Campbell L. Y., Kim, T., Schilling, W. M. \& Dinh T. N. T. (2018). Effect of deboning time on the growth of Salmonella, E. coli, aerobic, and lactic acid bacteria during beef sausage processing and storage. Meat Science, 139, 49-55.

Paper received: 12.09.2018.

Paper corrected: 22.05.2019.

Paper accepted: 21.05.2019.
Teodorović, V., Dimitrijević, M., Karabasil, N., Vasilev, D. (2015). Higijena i tehnologija mesa, Naučna KMD, Beograd, Srbija. ISBN: 978-86-81043-85-1.

Toldra, F. (2010). Handbook of Meat Processing, Ames, USA. ISBN: 978-0-8138-2182-5.

Tomasevic, I., Kuzmanovic, J., Anđelkovic, A., Sarcevic, M., Stojanovic, M., M. \& Djekic, I. (2016). The effects of mandatory HACCP implementation on microbiological indicators of process hygiene in meat processing and retail establishments in Serbia. Meat Science, 114, 54-57.

Thevenot, D., Delignette-Muller, L.M., Christieans, S. \& Vernozy-Rozand, C. (2005). Fate of Listeria monocytogenes in experimentally contaminated French sausages. International Journal of Food Microbiology, 101, 189-200.

Van Knapen, F., Kremers, A. F., Franchimont, J. H. \& Narucka, U. (1995). Prevalence of antibodies to Toxoplasma gondii in cattle and swine in The Netherlands: towards an integrated control of livestock production. Questions and Archive, 17, 87-91.

WHO. (2006). Five Keys to Safer Food, Department of Food Safety, Zoonoses and Foodborne Diseases, Geneva, Switzerland.

WTO. (1995). The Agreement on the Application of Sanitary and Phytosanitary Measures (SPS Agreement). https://www.wto.org/english/tratop_e/sps_e/spsagr_e. htm\#fntext1 (accessed on 08 May 2018). 